Article

\title{
Soil pH Responses to Simulated Acid Rain Leaching in Three Agricultural Soils
}

\author{
Hui Wei ${ }^{1,2,3}$, Yalan Liu ${ }^{1}$, Huimin Xiang ${ }^{1,2,3}$, Jiaen Zhang ${ }^{1,2,3, *}$, Saifei Li ${ }^{1}$ and Jiayue Yang ${ }^{1}$ \\ 1 College of Natural Resources and Environment, South China Agricultural University, \\ Guangzhou 510642, China; weihui@scau.edu.cn (H.W.); yisanghe@163.com (Y.L.); \\ hmxiang@scau.edu.cn (H.X.); lisf1994@163.com (S.L.); yangjiayue0123@163.com (J.Y.) \\ 2 Guangdong Provincial Key Laboratory of Eco-Circular Agriculture, Guangzhou 510642, China \\ 3 Key Laboratory of Agro-Environment in the Tropics, Ministry of Agriculture, South China Agricultural \\ University, Guangzhou 510642, China \\ * Correspondence: jeanzh@scau.edu.cn; Tel.: +86-20-8528-0211
}

Received: 25 November 2019; Accepted: 26 December 2019; Published: 30 December 2019

\begin{abstract}
Soil has the nature of acidity and alkalinity, mostly indicated by soil $\mathrm{pH}$ that could greatly affect soil ecological processes and functions. With exogenous inputs of acidic materials (such as acid rain), soils may more or less resist to maintain their $\mathrm{pH}$ levels within specific thresholds by various buffering processes. It has been well established that soil properties such as cation exchange capacity (CEC), soil organic matter (SOM), and clay content play important roles in mitigating the effects of acid inputs, but the factors varied across soils. This microcosm experiment was conducted to investigate changes in the soil $\mathrm{pH}$ and quantitatively estimate the critical $\mathrm{pH}$ threshold of simulated acid rain for three highly weathered soils (red soil, lateritic red soil, and latosol) that are typical soil types widely distributed across the world's subtropical and tropical climatic zones, as well as important influential factors, after continuously adding different levels of simulated acid rain on the surface of soil cores. The results showed that the change in the soil $\mathrm{pH}$ was not significantly different among the three soils, although it was exponentially related to soil CEC and clay content. Resultantly, the latosol that had high soil CEC and clay content was more resistant to simulated acid rain, especially when relatively weak simulated acid rain treatments were applied. The lateritic red soil that contained the lowest soil CEC and clay content showed the greatest decline in the soil $\mathrm{pH}$ under the strongest simulated acid rain treatment of $\mathrm{pH}$ being 2.5. Furthermore, we estimated the critical $\mathrm{pH}$ threshold of simulated acid rain for the three soils and observed that it was considerably different among the soils. Surprisingly, the $\mathrm{pH}$ threshold of simulated acid rain was also positively related to the soil CEC and clay content, therefore making the highest $\mathrm{pH}$ threshold in the latosol. Our results imply that soil CEC and clay content may play critical roles in the soil acid-buffering processes from two aspects; it could not only contribute to the soil acid-buffering capacity, but also affect the threshold of acidity of acid rain below which abrupt soil acidification may occur.
\end{abstract}

Keywords: acid deposition; critical load; soil acid-buffering capacity; soil acidity; soil $\mathrm{pH}$ buffering capacity

\section{Introduction}

Soil acidity is an important aspect of soil chemical properties and can influence ecosystem processes and functions to a great extent, e.g., by altering nutrient supplies via regulating the soil sorption/desorption reactions and properties of the soil microbial community [1-3]. Exogenous inputs of acidic materials in soils could result in soil acidification, i.e., increase soil acidity due to decreased acid neutralization capacity of soils [4,5], and therefore influence (mostly adversely) many ecosystem 
traits [6-8]. The atmospheric acid deposition, due to emission of acidic gases sulfur dioxide and nitrogen oxides mainly derived from anthropogenous activities, contributes obviously to soil acidification in many ecosystems [8,9], while other processes such as nitrogen $(\mathrm{N})$ cycling and application of $\mathrm{N}$ fertilizers appear to be of high importance to result in significant decreases in the soil acidity $[5,10]$. It remains a research hotspot to clarify how soil properties would change in response to acid deposition, regarding the severe conditions of acid deposition in a considerable proportion of land area across the world and uncertain impacts on terrestrial ecosystems [9,11,12].

Soil has the nature of acidity and alkalinity that can be presented by its $\mathrm{pH}$, but it, by itself, can also mitigate effects of inputting acidic materials to a certain extent for the maintenance of constant soil acidity, by means of various soil processes such as carbonate dissolution and cation exchange processes $[4,13,14]$. Namely, soil, as the associated integration of solid, liquid, and gas phases of various living and non-living materials, has acid-buffering capacity to resist exogenous inputs of acidic materials. High soil acid-buffering capacity means that the soil has a relatively high potential to alleviate effects of exogenous acid inputs. Existing knowledge demonstrates that multiple processes could be involved in the processes of soil acid buffering, with specific mechanisms working under various $\mathrm{pH}$ conditions [13]. For the carbonate-containing soils of high $\mathrm{pH}$, for example, acid neutralization by the dissolution reaction of carbonate may play a predominant role to produce the soil acid-buffering capacity, while the soil cation exchange capacity (CEC) could be more important in the noncarbonate soils [15]. In several types of strongly acidic soils that distribute widely across those low latitude regions of the earth, however, the hydrolysis reaction of aluminum bound to organic materials could be the major source of soil acid-buffering capacity [16]. This context dependence highlights the necessity to widely investigate the soil acid-buffering capacity in diverse ecosystems under the changing scenarios such as agricultural managements and global changes.

It has been widely accepted that, in theory, five phases may exist to buffer acid inputs for soils of various physiochemical properties (especially the soil $\mathrm{pH}$ ) and a specific type of materials and process-play to buffer the input of acids at different $\mathrm{pH}$ levels [13,14]. An increasing amount of evidence shows that the soil acid-buffering capacity can vary greatly (e.g., ranges from 27.2 to $188.5 \mathrm{mmol} \mathrm{kg}^{-1}$ $\mathrm{pH}$ unit $^{-1}$ in carbonate soils versus from 10.4 to $58.7 \mathrm{mmol} \mathrm{kg}^{-1} \mathrm{pH}$ unit $^{-1}$ in noncarbonate soils [15]) across ecosystems. The magnitude of soil acid-buffering capacity depends greatly on ecosystem traits such as the soil CEC and soil organic matter (SOM) [17,18], but anthropogenous activities such as agricultural managements could potentially modify the soil acid-buffering capacity [19-21]. Despite the increasing knowledge, the phase nature of soil acid-buffering capacity has been rarely studied. It remains an aspect of high importance to quantify the $\mathrm{pH}$ threshold of exogenous acid input under or above which the soil $\mathrm{pH}$ will be rapidly altered and the underlying influential factors.

The tropical and subtropical soils account for a considerable proportion of the global soil and play important roles to maintain stabilization of the global climate system [22-24]. However, they are highly vulnerable to environmental changes, including acidic depositions from the atmosphere on the earth, and often have relatively low acid-buffering capacity $[25,26]$, due to strong weathering and leaching under favorable climatic conditions. Moreover, almost all of existing studies considered potential effects of ecosystem or soil traits on the soil acid-buffering capacity, with acidity effects of exogenous acids rarely studied. Regarding the heterogeneous and changing acid rain conditions in many parts of the world, we conducted this study with following aims. First, we aimed to observe the soil $\mathrm{pH}$ changes in three types of soils under different levels of simulated acid rain. The three soils, with significantly different soil properties, are widely distributed at the study site and are the typical soils in the tropical and subtropical climatic zones with high temperature and a great amount of precipitation. We expected that simulated acid-rain-induced changes in the soil $\mathrm{pH}$ would differ in these three acidic soils of significantly different soil properties such as soil $\mathrm{pH}$, clay content, and CEC. Second, we expected that there existed a specific precipitation $\mathrm{pH}$ threshold or a given type of soil. When the acidity of acid rain exceeds the threshold, the soil $\mathrm{pH}$ would appear to rapidly decline in response to acid rain inputs. Moreover, the $\mathrm{pH}$ threshold of simulated acid rain would be 
context-specific, depending on soil types of various soil properties. We hypothesized that high soil CEC, SOM, and clay content would contribute to low $\mathrm{pH}$ threshold of simulated acid rain; in other words, the soils would be more resistant to acid rains and therefore difficult to reach the critical load that resulted in a rapid decline in the soil $\mathrm{pH}$ of the given soil.

\section{Materials and Methods}

\subsection{Site Description and Soil Preparations}

The study was conducted at the South China Agricultural University $\left(23^{\circ} 09^{\prime} 40^{\prime \prime} \mathrm{N}, 113^{\circ} 20^{\prime} 58^{\prime \prime}\right.$ E) in Guangzhou City, China. This region experiences a subtropical monsoon climate with obvious cool-dry and warm-wet seasons. In the study site, the average air temperature was around $22{ }^{\circ} \mathrm{C}$ and average precipitation in the recent decade reached up to $2084 \mathrm{~mm}$, of which the most ( 80\%) occurred in the warm-wet season ranging from April to September and the remaining rainfall in the cool-dry season from October to March.

Three types of soil, including the red soil, lateritic red soil, and latosol, were collected from Shaoguan City, Guangzhou City, and Zhanjiang City, respectively (Figure 1), which are located in their main distribution areas in Guangdong Province, China, and have experienced long-term agricultural practices. The three soils belong to Ferralosols in the Chinese soil taxonomy, corresponding to Oxisols in the US soil taxonomy [27], which are predominant soil types that distribute in the midsubtropical, south subtropical, and tropical regions in China, respectively, and contribute to $22.4,37.5$, and $5.2 \%$ of the land of Guangdong Province, China, respectively [28]. Despite the same climate type in all the three locations, distributions of the monthly average air temperature and precipitation during the last decade were a bit different among sites, possibly making different soil weathering and leaching processes. Combining with different pedogenesis, the three soils had significantly different soil properties such as $\mathrm{pH}, \mathrm{CEC}$, SOM content, and soil texture (Table 1). In each location, twenty $30 \mathrm{~cm} \times 30 \mathrm{~cm}$ subplots were randomly chosen to collect all the surface soil at depth of $0-20 \mathrm{~cm}$, which approximated to the depth of plough layer in these agricultural fields. Then, the soils were transferred back to the lab for air-drying and sieving to pass a $5 \mathrm{~mm}$ soil sieve prior to use for the following experiments.
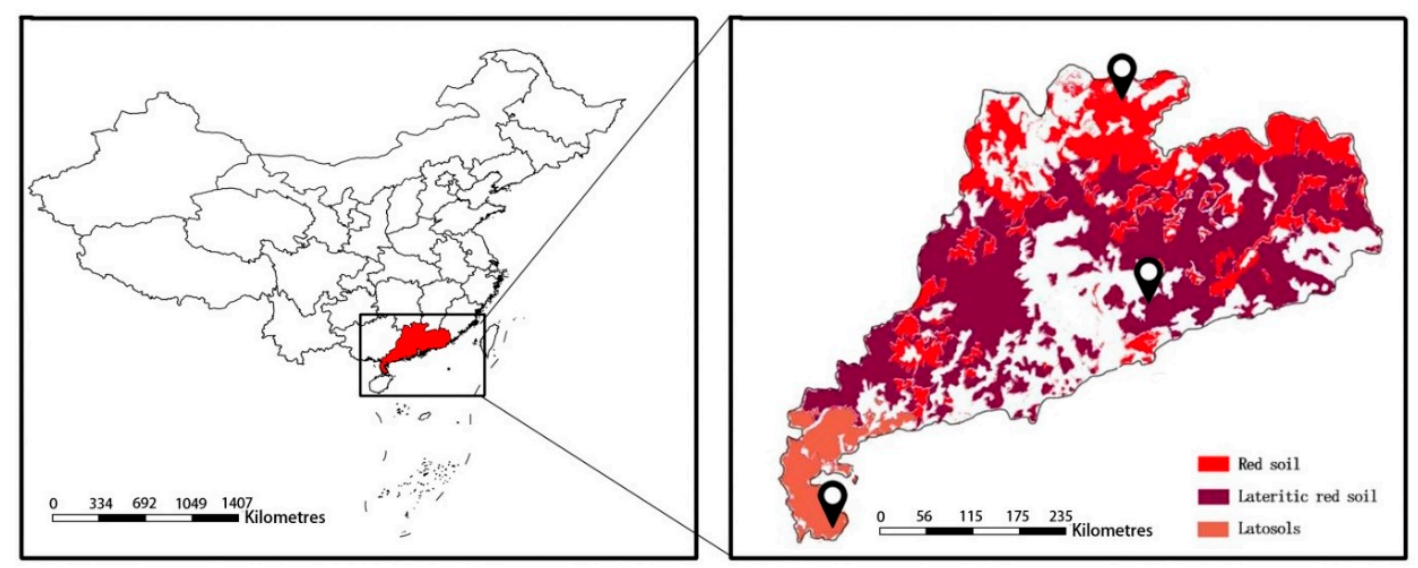

Figure 1. Distribution of the three types of acidic soils in Guangdong Province, China, and the locations of the three sampling sites. 
Table 1. The initial soil properties of the three agricultural soils tested in this study.

\begin{tabular}{|c|c|c|c|c|}
\hline & Red Soil * & Lateritic Red Soil & Latosol & \multirow{3}{*}{$F$ Value $^{+}$} \\
\hline Sampling Site & $\begin{array}{l}\text { Fuxi Town, Shaoguan } \\
\text { City, China }\end{array}$ & $\begin{array}{c}\text { Xintang Town, } \\
\text { Guangzhou City, China }\end{array}$ & $\begin{array}{c}\text { Nanshan Town, } \\
\text { Zhanjiang City, China }\end{array}$ & \\
\hline $\begin{array}{l}\text { Geographic } \\
\text { Coordinates }\end{array}$ & $\begin{array}{l}25^{\circ} 12^{\prime} 23^{\prime \prime} \mathrm{N}, \\
113^{\circ} 50^{\prime} 43^{\prime \prime} \mathrm{E}\end{array}$ & $\begin{array}{l}23^{\circ} 14^{\prime} 34^{\prime \prime} \mathrm{N} \\
113^{\circ} 37^{\prime} 50^{\prime \prime} \mathrm{E}\end{array}$ & $\begin{array}{l}20^{\circ} 18^{\prime} 31^{\prime \prime} \mathrm{N} \\
110^{\circ} 10^{\prime} 35^{\prime \prime} \mathrm{E}\end{array}$ & \\
\hline $\mathrm{pH}$ & $4.4 \pm 0.02 c$ & $5.2 \pm 0.01 \mathrm{~b}$ & $5.7 \pm 0.02 a$ & $1925.2 * * *$ \\
\hline $\mathrm{EC}\left(\mu \mathrm{S} \mathrm{cm}^{-1}\right)$ & $72.0 \pm 1.0 \mathrm{a}$ & $56.3 \pm 0.4 c$ & $59.5 \pm 0.7 b$ & $132.2^{* * *}$ \\
\hline CEC $\left(\mathrm{cmol} \mathrm{kg}^{-1}\right)$ & $9.6 \pm 0.08 b$ & $5.7 \pm 0.1 \mathrm{c}$ & $15.3 \pm 0.3 a$ & $811.7^{* * *}$ \\
\hline $\mathrm{SOM}\left(\mathrm{g} \mathrm{kg}^{-1}\right)$ & $28.1 \pm 0.4 \mathrm{a}$ & $17.4 \pm 0.2 \mathrm{c}$ & $25.0 \pm 0.3 b$ & $377.5^{* * *}$ \\
\hline Sand $(\%)$ & $46.0 \pm 0.6 b$ & $61.8 \pm 0.2 \mathrm{a}$ & $12.5 \pm 0.3 c$ & $4282.6^{* * *}$ \\
\hline Silt (\%) & $26.2 \pm 0.7 \mathrm{a}$ & $16.0 \pm 0.5 b$ & $27.8 \pm 0.3 a$ & $138.5^{* * *}$ \\
\hline Clay (\%) & $27.8 \pm 0.6 \mathrm{~b}$ & $22.2 \pm 0.4 c$ & $59.7 \pm 0.2 \mathrm{a}$ & $2101.5^{* * *}$ \\
\hline
\end{tabular}

* Results are presented as means \pm standard errors. The abbreviation of EC stands for soil electrical conductivity, CEC for soil cation exchange capacity, and SOM is soil organic matter. ${ }^{\dagger}$ Statistical $\mathrm{F}$ values are calculated by one-way analysis of variances, with ${ }^{* * *}$ indicating significance level at $p<0.001$. For each soil index, different lowercase letters indicate significant differences at $p<0.05$ among soil types.

\subsection{Experimental Design and Sample Analyses}

The experiment followed a two-factor completely randomized factorial design, with soil type and simulated acid rain treatment as the two factors. Soil type factor included three levels that were the red soil, lateritic red soil, and latosol, while five levels of simulated acid rain treatment constituted the control, $\mathrm{pH} 5.5, \mathrm{pH} 4.5, \mathrm{pH} 3.5$, and $\mathrm{pH} 2.5$ treatments. Four replicates were established for each of the combinations of the soil type and simulated acid rain treatment, and a total of 60 soil cores were prepared for incubation and leaching in this study. For each of the three soils, twenty soil cores were made for the simulated acid rain leaching by weighing $5 \mathrm{~kg}$ of the sieved soils into a circular plastic container that had an inner diameter of $20 \mathrm{~cm}$ and height of $20 \mathrm{~cm}$. Before preparing the soil cores, five holes with a diameter of $1 \mathrm{~cm}$ were made on the bottom of each container to permit leaching of water and a 100 mesh filter net was laid on the bottom to avoid soil loss in associations with leaching.

For the simulated acid rain treatments, the ion ratio of $\mathrm{SO}_{4}{ }^{2-}$ to $\mathrm{NO}_{3}{ }^{-}$was $4: 1$ in reference to the ratio of natural precipitation in the study site [29], and the total water amount was determined based on the annual precipitation and acid rain frequency within the time scale of 2013 to 2017 in Guangdong Province, China [30]. Combining with surface area of the soil core, a total of $18 \mathrm{~L}$ of the simulated acid rain or controlled water were applied in each soil core during the experimental period, with $600 \mathrm{~mL}$ applied once a day for 30 days. This approximately equals the annual amount of acid rain in this region $(574.2 \mathrm{~mm})$ [30].

At the end of the experiment, soil samples were collected to analyze the soil $\mathrm{pH}$ after mixing $10 \mathrm{~g}$ of soils with $25 \mathrm{~mL}$ deionized water, using a SX-620 pH meter (Shanghai Sanxin Instrumentation, Inc., Shanghai, China). Initial soil properties including soil $\mathrm{pH}$, electrical conductivity (EC), CEC, SOM, and soil texture were analyzed using air-dried samples before the incubation. The soil EC was determined using the potentiometry method by a Bante 902 conductivity meter (Shanghai Bante Instrumentation, Inc., Shanghai, China), with a ratio of soil to water being 1:5. The soil CEC was analyzed by the ammonium acetate exchange method, and the soil organic carbon content was determined by using the Walkley-Black method with $\mathrm{K}_{2} \mathrm{Cr}_{2} \mathrm{O}_{7}$ oxidization and $\mathrm{FeSO}_{4}$ titration, and then used to calculate the SOM content [31]. The soil samples were also used to determine the soil texture by the specific gravity count method [31].

\subsection{Statistics}

We calculated $\Delta$ soil $\mathrm{pH}$ to indicate changes in the soil $\mathrm{pH}$ under the treatments relative to the corresponding control prior to further data analyses. Data were tested as to whether they met the assumption of normality, and logarithm transformations were conducted when the assumption was violated. One-way analysis of variances (ANOVA) was used to detect the significant differences 
in the initial soil properties and changes in the soil $\mathrm{pH}$ among soil types or the soil $\mathrm{pH}$ changes among the simulated acid rain treatments in each soil. The Tukey method was used for the post hoc multiple comparisons when data met the assumption of homogeneity of variances; otherwise, the Games-Howell method was used. Two-way ANOVA was used to analyze the significance level of the main and interactive effects between soil type and the simulated acid rain treatment on the soil $\mathrm{pH}$. Furthermore, the One-Sample $T$ test was used to detect significant differences between changes in the soil $\mathrm{pH}$ in each soil under each of the simulated acid rain treatments and zero. Linear and exponential functions were used to fit the data between changes in the soil $\mathrm{pH}$ and initial soil properties. Moreover, a two-segment function was used to fit changes in the soil $\mathrm{pH}$ with changes in the $\mathrm{pH}$ of simulated acid rain, with the inflection points indicating precipitation $\mathrm{pH}_{\text {threshold }}$ under which soil $\mathrm{pH}$ rapidly decreased. All the statistical analyses were finished in IBM SPSS Statistics 22 (IBM Corp., Armonk, NY, USA), except for the function fitting conducted in SigmaPlot 10.0 (Systat Software Inc., San Jose, CA, USA). All the data were presented as means, with error bars indicating standard errors, and the significance level was set at $p<0.05$ for all the statistics.

\section{Results}

Two-way ANOVA showed that soil type and the simulated acid rain treatment significantly affected the soil $\mathrm{pH}(p<0.001)$, and the interactive effect between both was also statistically significant $(p<0.001)$. At the end of the experiment, the control treatment consistently increased the soil $\mathrm{pH}$ relative to the initial soil $\mathrm{pH}$ before the treatments in the three soils $(p<0.05)$, while the simulated acid rain treatments affected the soil $\mathrm{pH}$ positively $(p<0.05)$, neutrally $(p>0.05)$, or negatively $(p<0.05)$, depending on soil type and $\mathrm{pH}$ of the simulated acid rain. Relative to the control, the simulated acid rain treatments significantly reduced the soil $\mathrm{pH}$ by $6.8 \%, 7.0 \%$, and $5.1 \%$ in the red soil, lateritic red soil, and latosol, respectively, at the end of the experiment $(p<0.001$ for all, Figure 2$)$. When all the data were pooled under the simulated acid rain treatments for each soil, however, the acid-rain-induced changes in the soil $\mathrm{pH}$ were not significantly different among soil types ( $p=0.295$, Figure 2 ).

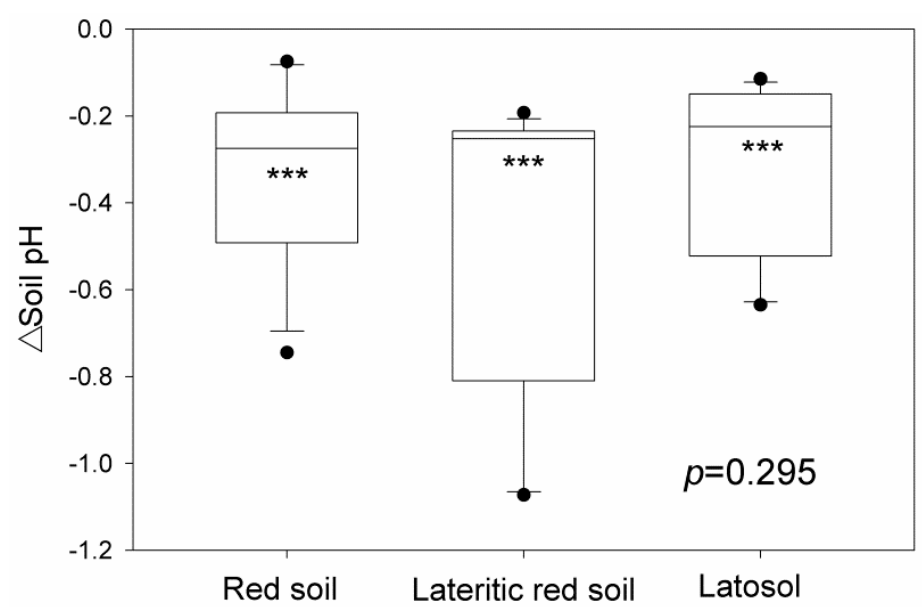

Figure 2. Changes in the soil $\mathrm{pH}(\Delta$ Soil $\mathrm{pH})$ under the simulated acid rain treatments relative to the control in the three soils. The statistical $p$ value is calculated by one-way analysis of variances to indicate the significance level of $\Delta$ Soil $\mathrm{pH}$ among soil types, while ${ }^{* * *}$ within each bar indicate that the mean $\Delta$ Soil $\mathrm{pH}$ is significantly different from zero at the significance level of $p<0.001$. Solid circles present outliers of the observed values identified by the interquartile range method.

Relative to the control, all the simulated acid rain treatments significantly decreased the soil $\mathrm{pH}$, regardless of soil type $(p<0.05$, Figure 3$)$. In the red and lateritic red soils, the simulated acid-rain-induced decrement was comparable among the $\mathrm{pH} 5.5, \mathrm{pH} 4.5$, and $\mathrm{pH} 3.5$ treatments $(p>0.05)$, but it was significantly greatest under the $\mathrm{pH} 2.5$ treatment $(p<0.05$, Figure $3 \mathrm{a}, \mathrm{b})$. In the latosol, however, the change in the soil $\mathrm{pH}$ under the $\mathrm{pH} 3.5$ treatment was significantly greater than 
that under the $\mathrm{pH} 5.5$ and $\mathrm{pH} 4.5$ treatments but significantly smaller than that under the $\mathrm{pH} 2.5$ treatment $(p<0.05$, Figure $3 \mathrm{c})$. For the red soil, the soil $\mathrm{pH}$ was reduced by $4.4 \%, 4.6 \%, 4.8 \%$, and $13.5 \%$ by the four acidity treatments relative to the control $(p<0.05)$, while the figure was $3.6 \%, 3.9 \%$, $4.5 \%$, and $16.1 \%$ for the lateritic red soil $(p<0.05)$, and $2.8 \%, 2.4 \%, 4.5 \%$, and $10.5 \%$ for the latosol $(p<0.05)$, respectively. Under the relatively weak simulated acid rain treatments (including the $\mathrm{pH} 5.5$ and $\mathrm{pH} 4.5$ treatments), $\Delta$ soil $\mathrm{pH}$ was slightly lower in the latosol than in the other two soils, with the difference being significant in the $\mathrm{pH} 4.5$ treatment $(p=0.006)$, while it was comparable among the three soils under the $\mathrm{pH} 3.5$ treatment $(p=0.513$; comparing Figure $3 \mathrm{a}-\mathrm{c}$ ). Under the strongest $\mathrm{pH} 2.5$ treatment, however, the soil $\mathrm{pH}$ was decreased the most in the lateritic red soil relative to the red soil and latosol $(p<0.001$; comparing Figure $3 \mathrm{a}-\mathrm{c})$. Changes in the soil $\mathrm{pH}$ exponentially increased with the increasing soil CEC and clay content (Figure 4).
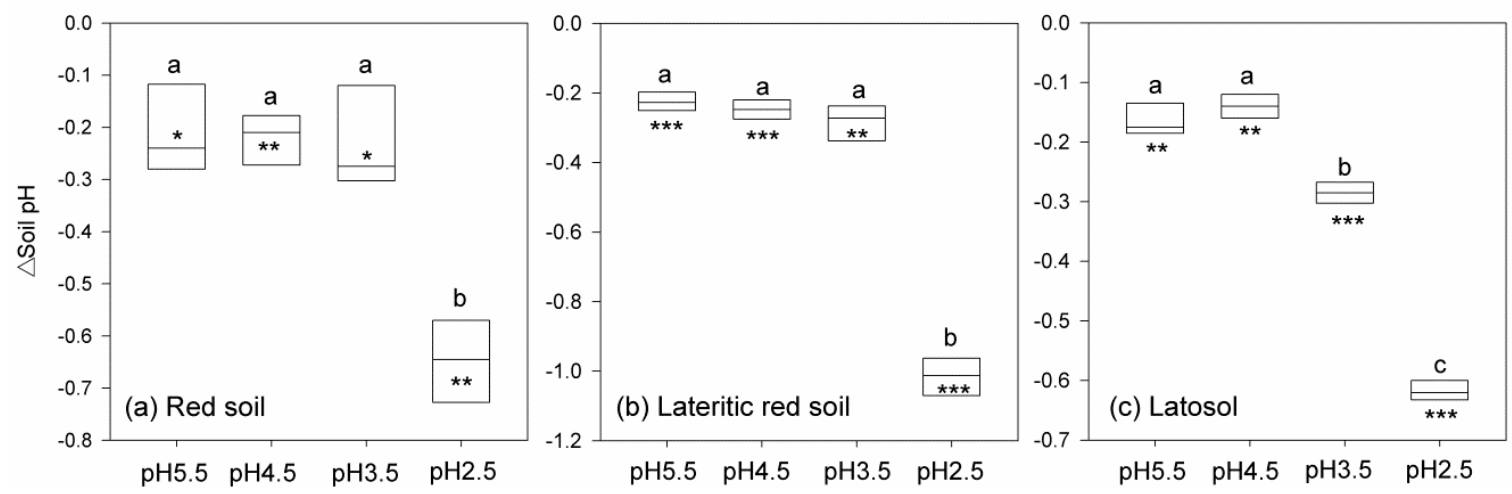

Figure 3. Changes in the soil $\mathrm{pH}$ under the simulated acid rain relative to the control treatments $(\Delta$ Soil $\mathrm{pH})$ in the three soils: (a) red soil; (b) lateritic red soil; (c) latosol. The $\mathrm{pH} 5.5, \mathrm{pH} 4.5, \mathrm{pH}$ 3.5 , and $\mathrm{pH} 2.5$ stand for the four levels of simulated acid rain treatments, with the $\mathrm{pH}$ of simulated acid rain being 5.5, 4.5, 3.5, and 2.5, respectively. In each panel, different lowercase letters above the boxes indicate significant differences among the treatments. The stars indicate that the $\Delta$ Soil $\mathrm{pH}$ is significantly different from zero, with ${ }^{*}, * *$, and ${ }^{* *}$ indicating the significance level of $p<0.05,0.01$, and 0.001 , respectively.
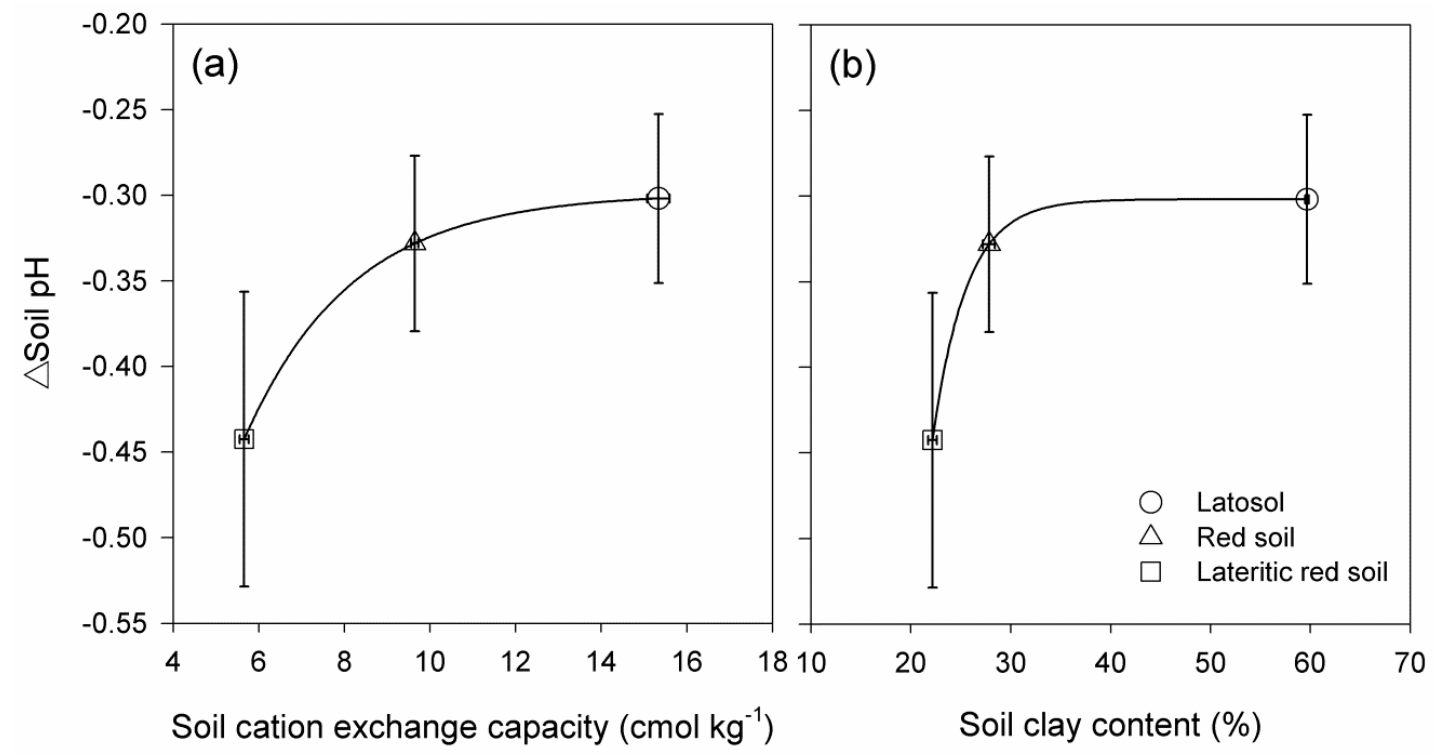

Figure 4. Dependence of Changes in the soil $\mathrm{pH}(\Delta \mathrm{Soil} \mathrm{pH})$ after treatments relative to the control on the soil cation exchange capacity (a) and clay content $(\mathbf{b})$. The signals present the mean values of $\Delta$ Soil $\mathrm{pH}$ for the three soils under different treatments. 
Furthermore, we used a two-segment function to fit soil $\mathrm{pH}$ changes along with $\mathrm{pH}$ of the simulated acid rain treatments and all the data were fitted well. The inflection point of the two-segment

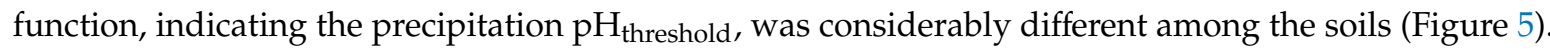
In particular, the $\mathrm{pH}_{\text {threshold }}$ was higher in the latosol (3.74) than in the red soil (3.12) and lateritic red soil (3.02) by $19.9 \%$ and $23.8 \%$, respectively, with the latter two comparable. Moreover, the $\mathrm{pH}_{\text {threshold }}$ was positively and exponentially related to the soil CEC and positively linearly related to the soil clay content across the soils (Figure 6).
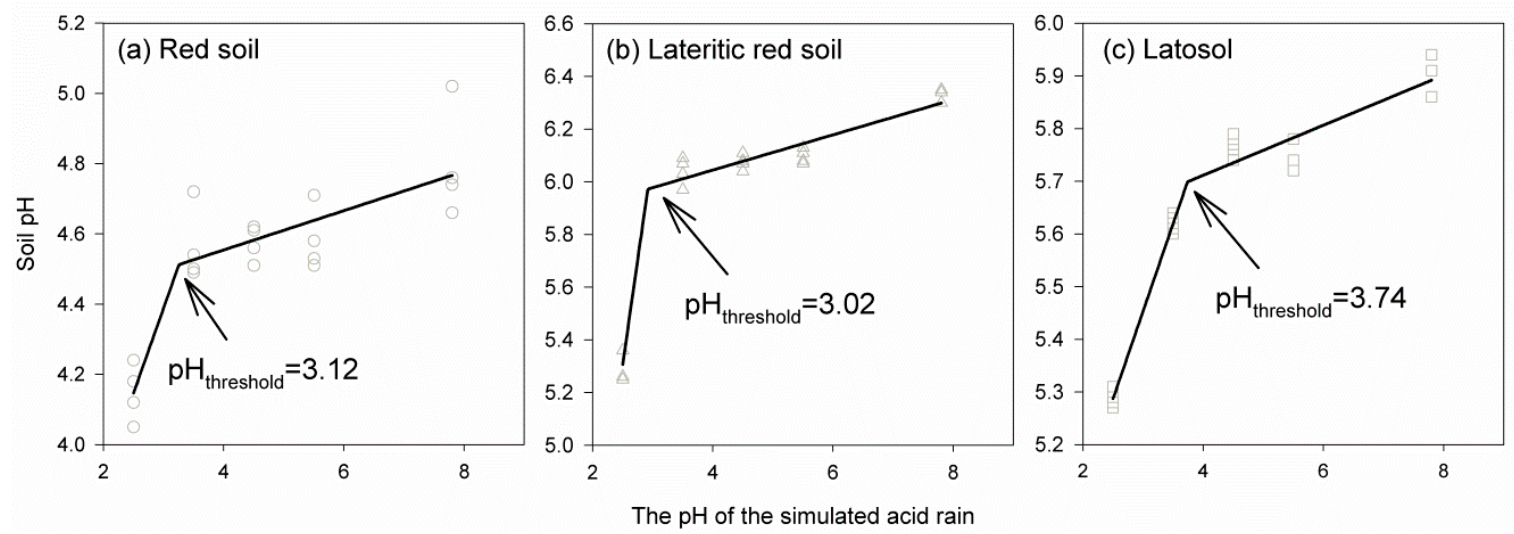

Figure 5. Changes in the soil $\mathrm{pH}$ in response to $\mathrm{pH}$ of the simulated acid rain in the three soils. The polylines are fitted using the two-segment function, with the inflection point indicating precipitation $\mathrm{pH}$ threshold $\left(\mathrm{pH}_{\text {threshold }}\right)$. The soil $\mathrm{pH}$ could rapidly decline when receiving an acid rain with $\mathrm{pH}$ below the threshold.
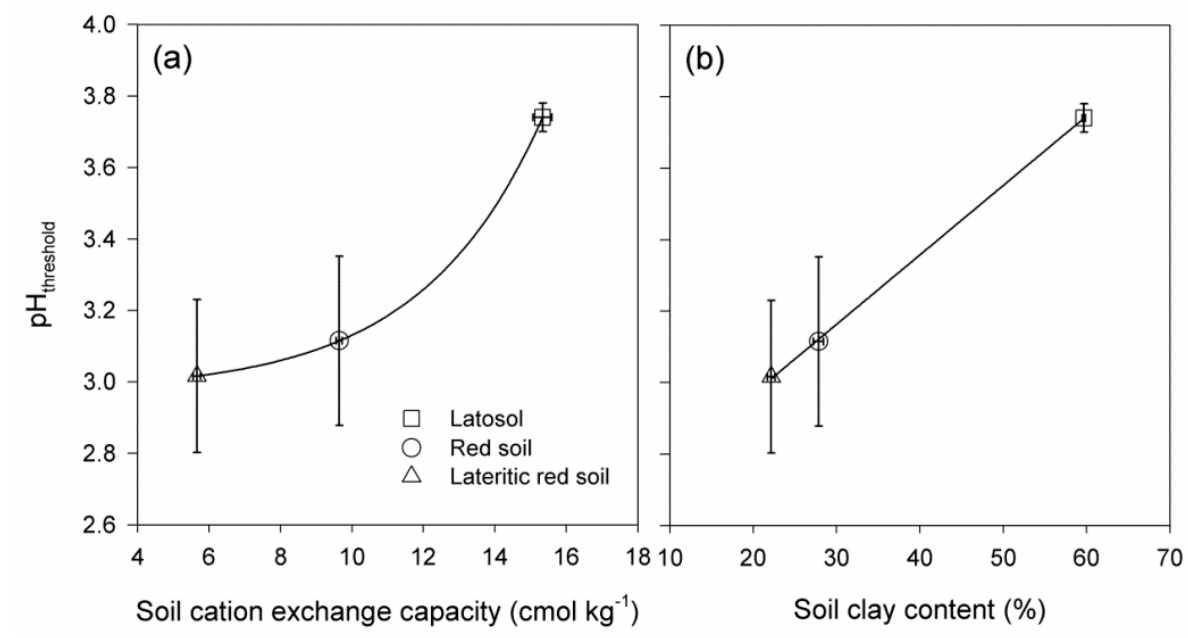

Figure 6. Dependence of the $\mathrm{pH}$ threshold of the simulated acid rain $\left(\mathrm{pH}_{\text {threshold }}\right)$ on the (a) soil cation exchange capacity and (b). clay content.

\section{Discussion}

Irrespective of acidity of the simulated acid rain, changes in soil $\mathrm{pH}$ under the simulated acid rain treatments relative to the control were not significantly different among the three types of acidic soil at the end of the experiment (Figure 2). This scenario suggests that the three soils may be comparably resistant to exogenous acid inputs, including the atmospheric acid depositions. That is to say, the three soils in this study, in spite of the considerably different soil properties including soil $\mathrm{pH}, \mathrm{CEC}$, and texture (Table 1), have similar soil acid-buffering capacity to maintain the soil $\mathrm{pH}$ under acid rain conditions. The observation is out of our expectation that soil $\mathrm{pH}$ changes under the treatments would differ among the soils of different properties, and seems to be inconsistent with previous observations of various acid-buffering capacities across soils that contain contrasting soil properties derived from 
natural processes or anthropogenous activities $[18,19,21]$. This discrepancy could, at least in part, be attributed to the significant interactive effects of precipitation acidity and soil type in the present study, despite the fact that we cannot figure out reasons to explain why such an interaction occurred based on our observations. While the treatment-induced changes in soil $\mathrm{pH}$ were compared among soils, a notable pattern was observed; relatively low acidity of the simulated acid rain treatments (i.e., $\mathrm{pH} 5.5$ and $\mathrm{pH}$ 4.5) exerted less effect on the soil $\mathrm{pH}$ in the latosol than in the red soil and lateritic red soil, whereas the strongest $\mathrm{pH} 2.5$ treatment led to the greatest $\mathrm{pH}$ decline in the lateritic red soil relative to the other two soils (Figure 3). This result suggests that soils could not maintain the constantly strong or weak acid-buffering capacity with exogenous acid inputs; in other words, the soil acid-buffering capacity for a given soil may be context-dependent and vary under different conditions of acidity.

Soil properties, especially the soil CEC and clay content (and sometimes including other factors such as $\mathrm{pH}, \mathrm{SOM}$, and aridity etc.), have been frequently suggested to affect the soil acid-buffering capacity to a great extent $[15,17,18]$. This is also supported by our observation that the soil CEC and clay content were exponentially related to changes in soil $\mathrm{pH}$ induced by the simulated acid rain treatments (Figure 4). Widely accepted knowledge demonstrates that soils can buffer exogenous acid input by means of multiple mechanisms derived from various processes $[4,13]$. Soil exchangeable cations, which greatly depend on soil $\mathrm{pH}, \mathrm{SOM}$, and clay [32-34], can exchange with exogenously input $\mathrm{H}^{+}$to mitigate its effect on the soil acidity. Therefore, positive linear relationships between the soil CEC and acid-buffering capacity have been frequently reported across studies $[15,18,35]$. Our results suggest that soil CEC could influence changes in soil $\mathrm{pH}$ with exogenous acid inputs exponentially (Figure 4a), and that, under acid rain conditions, the soil $\mathrm{pH}$ may rapidly change in these tropical and subtropical soils that have low soil CEC. Although a linear relationship between soil CEC and $\mathrm{pH}$ buffering capacity has been reported across eighteen soils [35], an exponential function to rise to maximum can be used to fit the same dataset comparably or even better than the linear function (e.g., adjusted R square is 0.74 in the exponential function versus 0.69 in the linear regression). Moreover, soil clay content was also potentially related to the treatment-induced changes in the soil $\mathrm{pH}$ (Figure $4 \mathrm{~b}$ ). This could be connected with a clay weathering process that releases base and alkali cations to neutralize acids [14], but the magnitude of neutralization may greatly depend on the type of clay minerals [35].

Furthermore, we observed that there existed obvious $\mathrm{pH}$ thresholds for these soils, and soil $\mathrm{pH}$ could decline rapidly under acid rain conditions with $\mathrm{pH}$ below the specific thresholds. This phenomenon is notable when we evaluate the consequences of acid rain in ecosystems, because the acid-rain-induced changes could be surprisingly abrupt to deteriorate soil environment once the acidity of acid rains exceeds the critical $\mathrm{pH}$ threshold. Such a $\mathrm{pH}$ threshold is similar with the critical load of acidity of acid rain as reported previously, because both of them are critical points below which soil or ecosystem properties will be dramatically altered. The term of critical load has been proposed and studied in relating fields. For instance, critical loads of soil $\mathrm{pH}$ were estimated across soils for soil amelioration to maintain high production of crops, critical loads of $\mathrm{N}$ deposition were estimated in different ecoregions of the United States, and critical loads of acidity of surface water were quantitatively studied in south-central Ontario, Canada [36-38]. To the best of our knowledge, however, the critical $\mathrm{pH}$ threshold of acid rains to result in rapid $\mathrm{pH}$ changes in different types of soils has been rarely studied, despite the fact that critical load of acid or sulfur deposition has been evaluated for forest health or soil acidification $[39,40]$. Once acidity of acid rains exceeds the $\mathrm{pH}$ threshold, soils under the acid rain conditions could be rapidly acidified and then result in dramatical changes in soil biota, rapid loss of soil nutrients, and activations of heavy metals [7,41,42].

Moreover, the $\mathrm{pH}$ threshold is considerably different among the three soils in this study (Figure 5), an observation supporting our expectation that soils with different physiochemical properties could have different tolerance capacity to acid stresses. However, the result of higher $\mathrm{pH}$ threshold in the latosol that has high soil $\mathrm{pH}$, clay content, and CEC is unexpected, because we thought the soil properties that are beneficial to buffering exogenous acid inputs would also maintain at a relatively low $\mathrm{pH}$ threshold for the given soil; in other words, it may be harder for the soils with higher soil 
acid-buffering capacity to reach the critical point below which soil $\mathrm{pH}$ will be rapidly reduced even under a comparable acid rain stress. On the contrary, positive relationships between the $\mathrm{pH}$ threshold and soil CEC or clay content were observed in this study (Figure 6). However, soil pH buffering capacity, as well as the $\mathrm{pH}$ threshold, should not be simply determined by the clay content, but also affected by other properties such as clay type and mineralogy. For instance, 2:1 clays such as hydroxy-interlayered vermiculite have greater soil $\mathrm{pH}$ buffering capacity, while some 1:1 clays could be more sensitive to the acid inputs due to their relatively lower $\mathrm{pH}$ buffering capacity [43]. Further studies combining microstructure and mineralogy analyses could be helpful to reveal the potential reasons of the observed relationships. Although the potential mechanisms deserve further studies, this scenario in the present study suggests that soils of higher CEC and clay content, with lower changes in the soil $\mathrm{pH}$ under acid rain conditions (Figure 4), could be easily affected by relatively weak acid rains. With the three soils as examples, acid rain of the $\mathrm{pH}$ being 3.5 could result in a rapid decline in the latosol, but it may only slightly decrease the soil $\mathrm{pH}$ in the red soil and lateritic red soil.

This was an exploratory study to quantitatively estimate the acidity threshold of acid rain for the acidic soils of different physiochemical properties. The results can help us to improve our understanding on how acid rains affect soil environmental conditions. However, our results should be read and extended with cautions due to the potential limitations of this type of microcosm experiment $[44,45]$. First, this study was conducted using disturbed soils (air dried, sieved, and restructured) for incubation. In spite of simplifications in experimental treatments and easier-to-obtain homogenous results relative to field experiments, the pretreatment processes may result in biased observations relative to in situ studies using undisturbed soils. Such treatment-induced biases would significantly affect quantitative analyses of soil properties, but pretreatments of soil samples (such as sieving and storage) may not influence the reliability when comparing results among experimental treatments [46], due to the same extent of disturbance exerted for all the treatment and control groups. Second, the simulated acid rain treatments were conducted continuously within the experimental period. This could not realistically occur in nature, although we collected acid rain conditions and calculated the total amount of acid rain in the last five years in the study site as references to determine the amount and $\mathrm{pH}$ levels of the simulated acid rain. The high-frequent treatment may result in underestimating the $\mathrm{pH}$ threshold, because ecosystem traits could be able to recover within the intervals of precipitation when the intervals are long enough [47]. Third, only three types of acidic soils were used in this experiment. This limits us to extend the results and conclusions to a broader area. Therefore, further broad investigations are needed.

\section{Conclusions}

The microcosm experiment was conducted to investigate changes in the soil $\mathrm{pH}$ in three types of acidic soils of southern China under simulated acid rain conditions, with the $\mathrm{pH}$ threshold being also estimated. The results showed that changes in the soil $\mathrm{pH}$ under the simulated acid rain treatments were not significantly different among the soils, with significantly lower magnitude of soil $\mathrm{pH}$ change at relatively weak simulated acid rain treatments in the latosol, but significantly highest response to the strongest simulated acid rain treatment in the lateritic red soil. This observation suggests that the soil acid-buffering capacity may not be constant, but context-dependent for a given soil. The soil CEC and clay content were exponentially related to changes in the soil $\mathrm{pH}$. Moreover, we quantitatively estimated the critical precipitation $\mathrm{pH}$ threshold for the three soils, with the soil $\mathrm{pH}$ abruptly declining when the precipitation acidity was lower than the threshold. Such acidity thresholds were considerably different among soils and positively related to the soil CEC and clay content. Our results imply that soil CEC and clay content may play critical roles in the soil acid-buffering processes; it could not only contribute to the soil acid-buffering capacity, but also affect the threshold of acidity of acid rain below which abrupt soil acidification may occur. Existence of $\mathrm{pH}$ threshold of acid rain indicates a nonlinear response property of soil $\mathrm{pH}$ for a given soil as acidity of acid rain changes, and various $\mathrm{pH}$ thresholds 
of acid rain across soils increase the complexity when predicting soil responses to the changing acid rain at different temporal and spatial scales.

Author Contributions: Conceptualization, J.Z., H.W., and H.X.; methodology, H.W. and H.X.; formal analysis, H.W. and J.Y.; investigation, Y.L. and S.L.; writing-original draft preparation, H.W.; writing-review and editing, H.W., Y.L., H.X., J.Z., S.L., and J.Y.; visualization, H.W. and J.Y.; supervision, J.Z., H.W., and H.X.; project administration, H.W.; funding acquisition, J.Z., H.W., and H.X. All authors have read and agreed to the published version of the manuscript.

Funding: This research was supported by the National Natural Science Foundation of China (U1701236) and Science and Technology Planning Project of Guangdong Province of China (2019B030301007).

Acknowledgments: Ruilong Wang, Hongru Li, Jiawen Zhong, Xiaoran Shan, and Xiaoqiao Ren are appreciated for their help on soil collections.

Conflicts of Interest: The authors declare no conflict of interest.

\section{References}

1. Franco, A.; Fu, W.; Trapp, S. Influence of soil $\mathrm{pH}$ on the sorption of ionizable chemicals: Modeling advances. Environ. Toxicol. Chem. 2010, 28, 458-464. [CrossRef] [PubMed]

2. Fierer, N. Embracing the unknown: Disentangling the complexities of the soil microbiome. Nat. Rev. Microbiol. 2017, 15, 579-590. [CrossRef] [PubMed]

3. Delgado-Baquerizo, M.; Oliverio, A.M.; Brewer, T.E.; Benavent-Gonzalez, A.; Eldridge, D.J.; Bardgett, R.D.; Maestre, F.T.; Singh, B.K.; Fierer, N. A global atlas of the dominant bacteria found in soil. Science 2018, 359, 320-325. [CrossRef] [PubMed]

4. Van Breemen, N.; Mulder, J.; Driscoll, C.T. Acidification and alkalinization of soils. Plant Soil 1983, 75, 283-308. [CrossRef]

5. Guo, J.H.; Liu, X.J.; Zhang, Y.; Shen, J.L.; Han, W.X.; Zhang, W.F.; Christie, P.; Goulding, K.W.T.; Vitousek, P.M.; Zhang, F.S. Significant Acidification in Major Chinese Croplands. Science 2010, 327, 1008-1010. [CrossRef]

6. Likens, G.E.; Butler, T.J. Acid rain: Causes, consequences, and recovery in rerrestrial, aquatic, and human systems. In Encyclopedia of the Anthropocene; Elsevier: Amsterdam, The Netherlands, 2018; Volume 5, pp. 23-31. [CrossRef]

7. Wei, H.; Liu, W.; Zhang, J.E.; Qin, Z. Effects of simulated acid rain on soil fauna community composition and their ecological niches. Environ. Pollut. 2017, 220, 460-468. [CrossRef]

8. Duan, L.; Yu, Q.; Zhang, Q.; Wang, Z.; Pan, Y.; Larssen, T.; Tang, J.; Mulder, J. Acid deposition in Asia: Emissions, deposition, and ecosystem effects. Atmos. Environ. 2016, 146, 55-69. [CrossRef]

9. Stevens, C.J.; Dise, N.B.; Gowing, D.J. Regional trends in soil acidification and exchangeable metal concentrations in relation to acid deposition rates. Environ. Pollut. 2009, 157, 313-319. [CrossRef]

10. Fenn, M.E.; Poth, M.A.; Aber, J.D.; Baron, J.S.; Bormann, B.T.; Johnson, D.W.; Lemly, A.D.; McNulty, S.G.; Ryan, D.F.; Stottlemyer, R. Nitrogen excess in North American ecosystems: Predisposing factors, ecosystem responses, and management strategies. Ecol. Appl. 1998, 8, 706-733. [CrossRef]

11. Yu, H.; He, N.; Wang, Q.; Zhu, J.; Gao, Y.; Zhang, Y.; Jia, Y.; Yu, G. Development of atmospheric acid deposition in China from the 1990s to the 2010s. Environ. Pollut. 2017, 231, 182-190. [CrossRef]

12. Rodhe, H.; Dentener, F.; Schulz, M. The global distribution of acidifying wet deposition. Environ. Sci. Technol. 2002, 36, 4382-4388. [CrossRef] [PubMed]

13. Chadwick, O.A.; Chorover, J. The chemistry of pedogenic thresholds. Geoderma 2001, 100, 321-353. [CrossRef]

14. Ulrich, B. Soil acidity and its relations to acid deposition. In Effects of Accumulation of Air Pollutants in Forest Ecosystems; Ulrich, B., Pankrath, J., Eds.; D. Reidel Publishing Company: Dordrecht, The Netherlands; Boston, MA, USA; London, UK, 1983; pp. 127-146.

15. Luo, W.T.; Nelson, P.N.; Li, M.H.; Cai, J.P.; Zhang, Y.Y.; Zhang, Y.G.; Yang, S.; Wang, R.Z.; Wang, Z.W.; $\mathrm{Wu}, \mathrm{Y} . \mathrm{N}$.; et al. Contrasting $\mathrm{pH}$ buffering patterns in neutral-alkaline soils along a $3600 \mathrm{~km}$ transect in northern China. Biogeosciences 2015, 12, 7047-7056. [CrossRef]

16. Bloom, P.R.; McBride, M.B.; Weaver, R.M. Aluminum organic matter in acid soils: Buffering and solution aluminum activity. Soil Sci. Soc. Am. J. 1979, 43, 488-493. [CrossRef]

17. Jiang, J.; Wang, Y.; Yu, M.; Cao, N.; Yan, J. Soil organic matter is important for acid buffering and reducing aluminum leaching from acidic forest soils. Chem. Geol. 2018, 501, 86-94. [CrossRef] 
18. Nelson, P.N.; Su, N. Soil pH buffering capacity: A descriptive function and its application to some acidic tropical soils. Aust. J. Soil Res. 2010, 48, 201-207. [CrossRef]

19. Zhang, Y.; Zhang, S.; Wang, R.; Cai, J.; Zhang, Y.; Li, H.; Huang, S.; Jiang, Y. Impacts of fertilization practices on $\mathrm{pH}$ and the $\mathrm{pH}$ buffering capacity of calcareous soil. Soil Sci. Plant Nutr. 2016, 62, 432-439. [CrossRef]

20. Zhang, Y.; de Vries, W.; Thomas, B.W.; Hao, X.; Shi, X. Impacts of long-term nitrogen fertilization on acid buffering rates and mechanisms of a slightly calcareous clay soil. Geoderma 2017, 305, 92-99. [CrossRef]

21. Shi, R.-Y.; Hong, Z.-N.; Li, J.-Y.; Jiang, J.; Abdulaha-Al Baquy, M.; Xu, R.-k.; Qian, W. Mechanisms for Increasing the $\mathrm{pH}$ Buffering Capacity of an Acidic Ultisol by Crop Residue-Derived Biochars. J. Agric. Food Chem. 2017, 65, 8111-8119. [CrossRef]

22. Jian, J.; Steele, M.K.; Thomas, R.Q.; Day, S.D.; Hodges, S.C. Constraining estimates of global soil respiration by quantifying sources of variability. Glob. Chang. Biol. 2018, 24, 4143-4159. [CrossRef]

23. Bond-Lamberty, B.; Bailey, V.L.; Chen, M.; Gough, C.M.; Vargas, R. Globally rising soil heterotrophic respiration over recent decades. Nature 2018, 560, 80-83. [CrossRef] [PubMed]

24. Scharlemann, J.P.W.; Tanner, E.V.J.; Hiederer, R.; Kapos, V. Global soil carbon: Understanding and managing the largest terrestrial carbon pool. Carbon Manag. 2014, 5, 81-91. [CrossRef]

25. Nguyen, T.; Tran, T.T.H. The contribution of various components to $\mathrm{pH}$ buffering capacity of Acrisols in southeastern Vietnam. Commun. Soil Sci. Plant Anal. 2019, 50, 1170-1177. [CrossRef]

26. Jiang, J.; Wang, Y.-P.; Yu, M.; Li, K.; Shao, Y.; Yan, J. Responses of soil buffering capacity to acid treatment in three typical subtropical forests. Sci. Total Environ. 2016, 563, 1068-1077. [CrossRef] [PubMed]

27. Gong, Z.; Zhang, G.; Chen, Z.; Luo, G.; Zhao, W. Soil reference on the bases of Chinese Soil Taxonomy. Chin. J. Soil Sci. 2002, 33, 1-5.

28. Institute of Soil Sciences. Soil Science Database; Institute of Soil Sciences: Nanjing, China, 2019.

29. Huang, D.Y.; Xu, Y.G.; Peng, P.; Zhang, H.H.; Lan, J.B. Chemical composition and seasonal variation of acid deposition in Guangzhou, South China: Comparison with precipitation in other major Chinese cities. Environ. Pollut. 2009, 157, 35-41. [CrossRef]

30. Lu, X. 2013-2017 Report on the State of Guangdong Provincial Ecology and Environment; Guangdong Provincial Department of Ecology and Environment: Guangzhou, China, 2018.

31. Bao, S. Agro-Chemical Analyses of Soils; China Agruculture Press: Beijing, China, 2000.

32. Bronick, C.J.; Lal, R. Soil structure and management: A review. Geoderma 2005, 124, 3-22. [CrossRef]

33. Helling, C.S.; Chesters, G.; Corey, R.B. Contribution of organic matter and clay to soil cation-exchange capacity as affected by the $\mathrm{pH}$ of the saturating Solution. Soil Sci. Soc. Am. J. 1964, 28, 517-520. [CrossRef]

34. Khodaverdiloo, H.; Momtaz, H.; Liao, K. Performance of Soil Cation Exchange Capacity Pedotransfer Function as Affected by the Inputs and Database Size. CLEAN Soil Air Water 2018, 46, 1700670. [CrossRef]

35. Xu, R.; Zhao, A.; Yuan, J.; Jiang, J. pH buffering capacity of acid soils from tropical and subtropical regions of China as influenced by incorporation of crop straw biochars. J. Soil Sediment 2012, 12, 494-502. [CrossRef]

36. Baquy, M.A.; Li, J.Y.; Shi, R.Y.; Kamran, M.A.; Xu, R.K. Higher cation exchange capacity determined lower critical soil pH and higher Al concentration for soybean. Environ. Sci. Pollut. Res. Int. 2018, 25, 6980-6989. [CrossRef] [PubMed]

37. Henriksen, A.; Dillon, P.J.; Aherne, J. Critical loads of acidity for surface waters in south-central Ontario, Canada: Regional application of the Steady-State Water Chemistry (SSWC) model. Can. J. Fish Aquat. Sci. 2002, 59, 1287-1295. [CrossRef]

38. Pardo, L.H.; Fenn, M.E.; Goodale, C.L.; Geiser, L.H.; Driscoll, C.T.; Allen, E.B.; Baron, J.S.; Bobbink, R.; Bowman, W.D.; Clark, C.M. Effects of nitrogen deposition and empirical nitrogen critical loads for ecoregions of the United States. Ecol. Appl. 2011, 21, 3049-3082. [CrossRef]

39. Duarte, N.; Pardo, L.H.; Robin-Abbott, M.J. Susceptibility of forests in the northeastern USA to nitrogen and sulfur deposition: Critical load exceedance and forest health. Water Air Soil Pollut. 2013, 224, 1355. [CrossRef]

40. Posch, M.; Duan, L.; Reinds, G.J.; Zhao, Y. Critical loads of nitrogen and sulphur to avert acidification and eutrophication in Europe and China. Landsc. Ecol. 2015, 30, 487-499. [CrossRef]

41. Jin, Z.S.; Liu, T.Z.; Yang, Y.G.; Jackson, D. Leaching of cadmium, chromium, copper, lead, and zinc from two slag dumps with different environmental exposure periods under dynamic acidic condition. Ecotoxicol. Environ. Saf. 2014, 104, 43-50. [CrossRef]

42. Jalali, M.; Naderi, E. The impact of acid rain on phosphorus leaching from a sandy loam calcareous soil of western Iran. Environ. Earth Sci. 2012, 66, 311-317. [CrossRef] 
43. Weaver, A.R.; Kissel, D.E.; Chen, F.; West, L.T.; Adkins, W.; Rickman, D.; Luvall, J.C. Mapping soil pH buffering capacity of selected fields in the coastal plain. Soil Sci. Soc. Am. J. 2004, 68, 662-668. [CrossRef]

44. Lawton, J.H. Ecological experiments with model systems. Science 1995, 269, 328-331. [CrossRef]

45. Benton, T.G.; Solan, M.; Travis, J.M.; Sait, S.M. Microcosm experiments can inform global ecological problems. Trends Ecol. Evol. 2007, 22, 516-521. [CrossRef]

46. Meyer, N.; Welp, G.; Amelung, W. Effect of sieving and sample storage on soil respiration and its temperature sensitivity (Q10) in mineral soils from Germany. Biol. Fert. Soils 2019, 55, 825-832. [CrossRef]

47. Belnap, J.; Phillips, S.L.; Miller, M.E. Response of desert biological soil crusts to alterations in precipitation frequency. Oecologia 2004, 141, 306-316. [CrossRef] [PubMed]

(C) 2019 by the authors. Licensee MDPI, Basel, Switzerland. This article is an open access article distributed under the terms and conditions of the Creative Commons Attribution (CC BY) license (http://creativecommons.org/licenses/by/4.0/). 